\title{
Understanding Trade-Related Aspects of Intellectual Property Rights Agreement: From Hard and Soft Law Perspective
}

\author{
Kholis Roisah \\ Faculty of Law, Diponegoro University, Indonesia. E-mail: r_kholis@yahoo.com
}

\begin{tabular}{l} 
ARTICLE INFO \\
\hline Keywords: \\
Hard Law; Intellectual \\
Property Rights; Soft Law; \\
TRIPs Agreement \\
How to cite: \\
Roisah, K. (2017). \\
Understanding Trade- \\
Related Aspects of \\
Intellectual Property Rights \\
Agreement: From Hard and \\
Soft Law Perspective. \\
Hasanuddin Law Review, \\
3(3): 277-289 \\
DOI: \\
10.20956/halrev.v3i3.1153
\end{tabular}

\begin{abstract}
Trade-Related Aspects of Intellectual Property Rights (TRIPs) Agreement interesting to be understood in the perspective of hard law and soft law. TRIPs Agreement justified as hard or soft law by identifying the norms in the TRIPs agreement. Parameter obligation of TRIPs agreement visible implementation and enforcement of agreement norm with full compliance to fourth of the IPR Convention for the State parties is an indicator of unconditional obligation. Parameters precision TRIPS agreement showed formulation of general obligation setting up the implementation of treaty obligations is regulated in detail and the use of "shall" term in any norm, describe the imperative norm character and shown indicator as substantial limited of interpretation with the parties might not interpreted. Parameter delegation looked explicitly provision of implementation and enforcement agreement that put an obligation on national authorities of state parties through domestic law and its courts. Parameter obligation, precision as well as delegation showed as high indicator that the TRIPs agreement characterized as hard law.
\end{abstract}

Copyright (C) 2017 HALREV. All rights reserved.

\section{Introduction}

International agreement plays a big role in relation between nations or relation between subjects of international law. Through international agreement, nations or subjects of international law highlight foundations of cooperation between them, organize various inter-state activities, solve various inter-state problems, and solve various global issues ${ }^{1}$ for the sake of a better and mutual life international society. Dependency between a country and another country in this era has become inevitable. There is no country or subject of international law that is not bound by international agreement. An agreement that essentially is the source of international law is a

1 Winarno, B. (2011). Isu-isu Gobal Kontemporer. Yogyakarta: CAPS, p. 16. Global Issues are problems, dilemmas as well as challenges related to the basic needs of international peace, security order, justice, fredoom and progressif development. 
juridical instrument that accommodates mutual will and goal of a country/subject of international law in order to reach certain goal. International agreement is the foundation of international law and regulates activities of countries/subjects of another international law.

International agreement is basically agreements or accords made by parties that have authority based on international law. According to Kusumaadmadja, ${ }^{2}$ international agreement is agreements made between society members of nations and aimed at generating certain legal consequences. Therefore, to be an international agreement, an agreement has to be made by subjects of international law that become the members of international community.

Nowadays, Trade related Aspect of Intellectual Property Rights (TRIPs) agreement is a phenomenal agreement in the order of international society and even becomes one of issues in this globalization and liberalization era. Particularly, since it became one of agendas in Uruguay Round that ran from 1986 to 1994. This round resulted in the establishment of World Trade Organization (WTO), and in this agreement also TRIPs Agreement was made. ${ }^{3}$ More than 150 countries around the world has ratified this agreement. This agreement has confirmed more strict law enforcement and widened the scope of Intellectual Property Rights beyond the previous international agreement initiated by World Intellectual Property Organization (WIPO), such as Bern Convention, Paris Convention, Rome Convention and Washington Treaty.

Substantive provision or norms covered in TRIPs agreement in the perspective of international agreement law (the practice of the making of international agreement) are classified as law making treaties, that is an international agreement containing universal general principles that can be imposed on all international society or all countries around the world 4 . However, TRIPs agreement as a law-making agreement has slightly different characteristics compared to law making agreement in general. TRIPs agreement covers more about provisions related to norms and minimum standard of Intellectual Property Rights protection ${ }^{5}$ that must be implemented by the party countries in this case all country members of WTO in their own national law. This is different with agreement points in Uruguay Round (agreement in the frame of GATT). In Uruguay Round, the agreement covers more concrete aspects such as market access and rate. These TRIPs agreement is an effort to create law to reinforce and widen more the provisions of Intellectual Property Rights protection that has been set previously in some international agreements.

2 Kusumaatmadja, M. (1982). Pengantar Hukum Internasional, Buku I Bagian Umum. Bandung: Rosda Offset, p. 109-110. Compared to Shaw, M.N. (2003). International Law, Fifth Edition, Cambridge University Press, p. 811

3 TRIPs Agreement is one of 15 agreements of the Final Act Embodying the Result of the Uruguay Round of Multilateral Trade Negotiations along with Agreement Establishing the World Trade Organization.

4 Kusumaatmadja, M. (1982). Op.Cit., p. 114

5 See: Article 1(1), Nature and Scope of obligation : Member shall give effect to the prevention of this Agreement. Member may, but shall not be obligated to implement their law more extensive protection than is required by this Agreement, ... Member shall be free determine the appropriate method of implementing the provision of this Agreement within their own legal system and practice. 


\section{Understanding Hard Law and Soft Law}

According to international law literature, the definition of hard law (HL) and soft law (SL) still becomes a debate. According to Shaffer and Pollack ${ }^{6}$, the debate about the definition of Hard Law and Soft Law among the experts of international law and international relation comes from positivist, constructivist and institutionalist rational views. Positive view of law relates the difference of hard law and soft law to the dichotomy of legally binding power while constructivists understand soft law and hard law by seeing law as a part of social interaction. Meanwhile, institutional rationalists apply multidimension view and sustainable view toward soft law and hard law.

In order to distinguish hard law and soft law, in general positivist law scholars is simply looking at whether an international agreement is binding or not. According to this view, typical character of law is a group of norms that have sanctions binding the actors by emphasizing on legal obligation. Basic difference between hard law and soft law is in the difference among the legal commitments of the actors or law subjects to be bound or not to be bound to international agreement ${ }^{7}$. In general, hard law is defined as an agreement that has legally binding power while soft law is defined as an agreement that is only morally or non-legally binding. The identification of both form of the agreement can be recognized from the name of the agreement. Hard law generally will use convention, covenant, protocol and treaty terms. Meanwhile, soft law is usually named using declaration, recommendation, code of conduct and action plan terms.

On the other hand, constructivist scholars focus less on formal provision of law that is seen on one point of time, in terms of the activation steps. They see law as part of social interaction process that can shape mutual understanding of proper social behavior. Constructivists said that it is too superficial to see soft law and hard law only by seeing the implementation of the agreement by the court without seeing how the law operates normatively as part of interactional process. Constructivists explicitly discuss how international law can cause a state to change their perception about their interest through transnational interaction process, discussion, persuasion, or acculturation. Thus, the creation of soft law or hard law may not reflect preference at all, but it is accumulation and gradual transformative effect of mutual understanding and state practice from time to time. 8

Institutionalist rational approach that is most influencing in explaining hard law and soft law concept is theory of "legalization" by Kennet. ${ }^{9}$ Legalization is special form of institutional cooperation. Legalization describes how mutual decision of involved countries can form international cooperation agreement. Furthermore, legalization concept sees consequences of actors involved based on the form or degree of the chosen legalization, soft law and hard law. As a parameter in measuring the level of legalization of an agreement or international cooperation, there are 3 dimensions that must be seen, consisting of Obligation, Delegation, and Precision.

6 Shaffer, G., and Pollack, M.A. (2012). "Hard and Soft Law: What Have We Learned?" Minnesota Legal Studies Research Paper No. 12-17. Available at SSRN: https://ssrn.com/abstract $=2044800$

$7 \quad$ Ibid.

8 Brunnée, J., and Stephen J.T. "Constructivism and International Law," in Dunoff, J.L., and Pollack, M.A. (eds.). (2012). International Law and International Relations: Synthesizing Insights from Interdisciplinary Scholarship. New York: Cambridge University Press, p. 3-4

9 Abbott, K.W., \& Snidal, D. (2000). "Hard and Soft Law in International Governance." International Organization, 54(3), 421-456. 
Obligation means the attachment of a country to fulfil obligation or commitment stated in an agreement. Therefore, the behavior of the country is restricted by a set of rules or commitment. There are six indicators of obligations: (1) Unconditional obligation; (2) Political treaty: implicit conditions on obligation; (3) National reservation on specific obligation; contingent obligations and escape clauses; (4) Hortatory obligations; (5) Norms adopted without law-making authority; recommendations and guidelines; and (6) Explicit negation of intent to be legally bound.

Precision of the rules written clearly and not ambiguous has become reference for actors' behaviors bound by the law. In the other words, precision gives valid limit in interpreting meaning of articles in an agreement. Delegation is how far a country or actor of international relation gives authority to the third party (including here international trial, arbitration institution, and administration organization) to run an agreement.

The higher the dimension of obligation, precision and delegation degree, the higher the legalization of an international law. Conversely, the lower the dimension level of obligation, precision and delegation, the lower the level of legalization. These three dimensions cannot be seen as single factors that determine the form of legalization. Each of those aspects can have either high or low level or degree, but to see legalization level, an international law is seen as a process that covers a multidimensional unity. If the three aspects are high, hard law is considered ideal. ${ }^{10}$ In this context, hard law and soft law can be defined by looking at the content of an agreement based on the quality of instrument given along with the three dimensions. ${ }^{11}$

Abbot and Snidal,12 defined soft law as residual category. In soft law domain, the setting of law weakens at one or more dimensions of obligation, precision, and delegation. Thus, if an agreement is not formally binding, it is weak at one dimension. Similarly, if an agreement is formally binding, but the content is vague so that there is a chance of discretion in the level of its implementation by the parties, it is said that the agreement is weak at the second dimension. Finally, if an agreement does not delegate any authority to third party to monitor its implementation or to interpret and enforce it, this agreement is weak (at the third dimension).

Accordingly, a country's motive in choosing one of the agreement formats will be noticed. At that point, cost-benefit analysis is determined which is borrowed from rational approach in international relation study. Advantages that a state can get by making hard law instrument are avoiding high transactional cost, strengthening the credibility of the state's commitment, extending political scope. Meanwhile, the weaknesses are eroding the sovereignty of a state and difficulty in adapting changes. The advantages of having law instrument in the form of soft law are firm sovereignty of a state, the ease of reaching agreement, more flexibility in facing changes and adapting norms. Meanwhile the weaknesses is difficulty in implementing the provisions because it is normative. This legalization concept will certainly enrich the scholars' insights of international law because our analysis of an international agreement will be more comprehensive.

$10 \quad$ Ibid., p. 421

11 Boyle, A.E. (1999). “Some Reflections on the Relationship of Treaties and Soft Law," International Law Quarterly, 48, (4): 901.

12 Benvenisti, E., and Hirsch, M. (Eds). (2004). The Impact of International Law on International Cooperation: Theoretical Perspectives. New York: Cambridge University Press, p. 38. 


\section{TRIPs Agreement in Hard Law and Soft Law Perspective}

Identify norms reflected in TRIPs agreement in order to distinguish between hard law and soft law, in this case author used theory of legalization by Kennet Abbot aforementioned. According to theory of legalization, to identify whether TRIPs agreement is hard law or soft law can be seen from three dimensions: Obligation, Precision, and Delegation.

\subsection{Obligation Dimension in TRIPs Agreement}

Obligation in TRIPs agreement is defined as an attachment of a state member of WTO to fulfil obligation in a TRIPs agreement. Thus, the action of the state member of WTO is restricted by a set of general rules, procedures contained in TRIPs agreement. In order to understand whether TRIPs agreement is hard law or soft law in obligation dimension, a thorough identification of the content of TRIPs agreement is necessary, particularly on articles that regulate the binding power of TRIPs agreement. The following is the degree of obligation level of TRIPs agreement is analyzed by examining its articles:

a) Part I explains general obligation that must be done by the parties involved in TRIPs agreement.

b) General obligation that must be done by the parties (all members of WTO) is enacting the standard of Intellectual property Rights protection based on the provisions regulated in TRIPs agreement. ${ }^{13}$ For all states or legal entities of all countries members of WTO based on Bern Convention about Protection of Copyright of knowledge and art (revision 1971), Paris Convention about Protection of Industrial Ownership (revision 1967), Roma Convention about Protection of associated right and Washington Treaty (1989) about Integrated Circuit Protection. ${ }^{14}$

c) Obligation to implement the principle of National Treatment. Based on national treatment, every country member of WTO has obligation to give protection to Intellectual Property Rights of their citizens. Protection meant here covers all things influencing existence, earning, scope, implementation and enforcement of Intellectual Property Rights; thoroughly as well as all things that can influence the use of Intellectual Property Rights (Article 3).

d) Obligation applies the principle of most favored-nation (MFN). Based on this principle, in order to implement protection to the owner of Intellectual Property Rights, all profit, benefits or special treatment given to the owner of Intellectual Property Rights of other country citizen immediately without any requirements are also given to the owner of Intellectual Property Rights of citizens of all countries members of WTO. In the other words, all treatment given by the countries member to foreign Intellectual Property Rights must be the same without any difference or non-discrimination (Article 4).

Part II explains obligation that must be done by the parties involved in TRIPs agreement to give protection of Intellectual Property Rights based on Chapter 1 until 7 Chapter II according to the provision of TRIPs agreement that covers:

13 Article 1 (1): Members shall give effect to the provisions of this Agreement.

14 Members shall accord the treatment provided for in this Agreement to the nationals of other Members. In respect of the relevant intellectual property right, the nationals of other Members shall be understood as those natural or legal persons that would meet the criteria for eligibility for protection provided... 
(1) Copyright and Related Rights. In the field of copyright, this agreement applies the concept of rental rights 15 and reapplies the actor rights, phonogram procedure and broadcast. ${ }^{16}$ For computer program, this agreement gives protection to literary works based on Bern Convention 1971. However, this has affirmed in Article 9 section (2) that protection must be extended to expressions and not on ideas that allows reserve engineering.

(2) Trade Mark. This TRIPs agreement lists the definition of trade mark and also announcement institution ${ }^{17}$. What is important in the provisions related to brand or trade mark is to extend the enactment of Article 6 Paris Convention (provision about famous brand) for service ${ }^{18}$ and good that is not in the same type with certain requirements. ${ }^{19}$ The length of time of the brand protection is not more than 7 years, 20 and the requirement of not using the brand for three years is not absolute requirement for the deletion of a brand.

(3) Obligation to give protection based on geographical indication is extended to all types of indications particularly wine and alcoholic beverages. ${ }^{21}$ For the protection of geographical indication, reputation will not be applied as the only criterion to determine the eligibility to obtain protection anymore. Geographical indications based on this agreement include qualities and other characters of good attached on the geographical origin. This agreement also covers protection of geographical indication individually. Various provisions have been covered in this agreement especially about geographical indication for the utilization of geographical indication that exists or is enacted in a country before the enactment of this agreement. ${ }^{22}$

(4) Industrial Design. Obligation to give protection must be given to industrial design created independently without distinguishing between new design and original design. ${ }^{23}$ Based on Article 26 of this agreement, the owner of industrial design enjoys exclusive right without any specific obligation. ${ }^{24}$

(5) Patent. Based on section 5 Article 27 of this agreement, country members is required to give protection to patent of products or processes in all fields of technology under condition that the products or processes contain novelty involving creation/invention stage that is invention step and is able to be applied in industry (useful and capable of industrial application). ${ }^{25}$ Protection must be

15 Article 3: "Each Member shall accord to the nationals of other Members treatment no less favorable than that it accords to its own nationals with regard to the protection of intellectual property..."

16 Article 10 (1): "In respect of a fixation of their performance on a phonogram, performers shall have the possibility of preventing the following acts when undertaken without their authorization"

17 Article 15 (4): "Members shall publish each trademark either before it is registered or promptly..."

18 Article 16 (2): "Article 6bis of the Paris Convention (1967) shall apply, mutatis mutandis, to services..."

19 Article 16 (3): "Article 6bis of the Paris Convention (1967) shall apply, mutatis mutandis, to goods or services which are not similar to those in respect of which a trademark is registered..."

20 Article 18: "Initial registration, and each renewal of registration, of a trademark shall be for a term of no less than seven years. The registration of a trademark shall be renewable indefinitely."

21 Article 23 (1): "Each Member shall provide the legal means for interested parties..."

22 Article 24 (3): "A Member shall not diminish the protection of geographical indications that existed..."

23 Article 25: "Members shall provide for the protection of independently created industrial designs that are new or original..."

24 Article 26: "The owner of a protected industrial design shall have the right to prevent third parties not having the owner's consent from making..."

25 Article 27 (1): "Patents shall be available for any inventions, whether products or processes, in all fields of technology, provided that they are new, involve an inventive step and are capable of industrial application. 
implemented without discrimination regarding place of invention, or field of technology or the origin of the products or processes (imported or local).

(6) Obligation to extend the provisions based on Washington Treaty by broadening protection to integrated circuit design of certain entities that is incorporated or is part of integrated circuit design of an entity is a reproduction of a valid integrated circuit design. Meanwhile, the length of time of the protection is lengthened to 10 years.

(7) Obligation to give protection to trade secret/undisclosed information. This is the extension of Intellectual Property Rights scope.

Part III explains about the obligation of the parties to implement the enforcement of protection to the violation of Intellectual Property Rights through mechanism or procedure that has been formulated in detailed and obligation to apply the procedure through judicial authority in a party country.

(1) Obligation to apply injunction judicial procedure in order to prevent the violation of Intellectual Property Rights as well as procedure to obtain assistance from customs institution in order to prevent the import of fake goods. ${ }^{26}$

(2) Obligation to give authority to judicial authority to order the replacement of loss to the owner/holder of intellectual Property Rights as a result of Intellectual Property rights. ${ }^{27}$

(3) Obligation of the parties to apply customs procedure that has been formulated in detailed against the violation of Intellectual Property rights either based on the report of the owner of the right or the actions of customs officers (Article 51 to 60).

(4) Obligation of countries members of WTO to apply crime procedure, including jail punishment and adequate fine so that it becomes prevention over crime actions related to the use of other parties' trade mark and copyright in forgery or piracy action in quite massive commercial scale.

Part V lists the obligation to conduct the principle of transparency, meaning that regulations and Acts as well as final judicial decree and also administrative rules of general treatment, that are implemented in the country members regarding the main problem on the agreement (the use, scope, acquisition, enactment and prevention of misuse of Intellectual Property Right), must be announced, or if the announcement cannot be made public or in national language, with any possible way that can be done through the cooperation of the government and the owner. Agreement about main problem in this agreement valid between government and government institutions of country members and government or government institution of other country member (Article 63). Obligation to settle a dispute between the parties is based on the provisions XXII and XXIII of GATT 1994 (Article 64), the settlement of a dispute has to be done through WTO Disputes Settlement Bodies.

Subject to paragraph 4 of Article 65, paragraph 8 of Article 70 and paragraph 3 of this Article, patents shall be available and patent rights enjoyable without discrimination as to the place of invention."

26 Article 44 (1): "The judicial authorities shall have the authority to order a party to desist from an infringement, inter alia to prevent the entry into the channels of commerce in their jurisdiction of imported goods that involve the infringement of an intellectual property right, immediately after customs clearance of such goods."

27 Article 45 (1): "The judicial authorities shall have the authority to order the infringer to pay the right holder damages adequate to compensate for the injury the right holder has suffered because of an infringement of that person's intellectual property right by an infringer who knowingly, or with reasonable grounds to know, engaged in infringing activity." 
Part VI regulates obligation of the parties to impose the provision of TRIPs agreement:

(1) For the party of developed countries, the obligation to impose provisions of TRIPs agreement before period one after the enactment of this agreement;

(2) For the party of developing countries, the obligation to impose the provisions of TRIPs agreement in four years after the period of the enactment of TRIPs agreement;

(3) For the party of under developing countries, the obligation to impose the provisions of TRIPs agreement in ten years after the period of the enactment of TRIPs agreement.

The last part of this agreement (part VII) regulates the obligation of TRIPs Council to monitor the implementation of the agreement by the parties (all members of WTO) particularly the one associated to the obedience of the members to do the contents of TRIPs agreement (Article 68). In addition, according to all provisions in this agreement, reservation (requirements) is not possibly done by the parties without agreement from other parties.

Obligations that have to be done by the parties (in this case all countries in WTO), from general obligation (Part I) to the obligation of the implementation of the agreement aforementioned describe a degree of obligation, with the highest degree is unconditional obligation or in this case the parties is not given a chance to propose requirements apart from the agreed requirements as obligations that must be done by the parties. At the same time, these obligations show a very string binding power of TRIPs agreement.

\subsection{Dimension of Precision in TRIPs Agreement}

Precision means that the existing regulations in international agreement containing standard norms of Intellectual Property Rights Protection are stated clearly and detailed. This means that those regulations specifically contain certain provisions that must be obeyed. This also means that the provisions in the associated agreement unambiguously become reference of conduct that is needed, validated/allowed or prohibited. The emphasis is on the degree of the detail of the words used in those regulations. The more detailed or specific the words used, the narrower the scope of the interpretation. Therefore, it will not cause multi interpretation that can result in fraud or the misuse of gap in-law. Conversely, the more generic the words used, the more the interpretation and the weakness. Thus, the possibility of the occurrence of violation is getting bigger. The following part will analyze the degree of precision in TRIPs agreement to know whether the law is hard or soft.

Part I formulates in detailed general obligation that must be done by the parties, consisting of 8 articles. The use of the word "shall" shows strong imperative so that it does not arise other interpretations besides the statement that all members of WTO have to implement the protection in some Intellectual Property Rights categories (based on formulation of Chapter 1 to 7 Part II) according to minimum standard of protection covering availability, procurement, scope, maintenance and enforcement of Intellectual Property Right that has been formulated clearly by referring to and following Paris Convention 1967, Bern Convention 1971, Rome Convention, and Washington Treaty 1989 (Article 1 and 2), obligation to apply the principle of national treatment (Article 3,5 and 6), the principle of most favored nation (Article 4,5 and 6) for the protection and settlement of dispute. 
Part II consisting of 7 Chapters and 31 Articles formulates necessity to do the obligation in detailed. The formulation of this necessity is not only arising from the four conventions mentioned, but also formulating new obligation that basically broadens the scope of its activation, the length of Intellectual Property Rights protection. The field of copyright arises new necessity to give protection to computer program and data compilation, and the length of the protection is extended to become 50 years. In the field of rights, the scope of the protection is extended to the actor, broadcast right and recording producer.

In the field of trade mark, the protection of Article 6 Paris Convention is extended by applying mutatis mutandis for service products and different type of products. There is necessity to extend the protection of geographical indication particularly for wine and alcoholic beverages products. Patent protection that can be given includes microorganism, non-biological process and biological process. Type of plants is also protected by pate. Protection is also extended in order to cover food, chemical, and pharmacy products as well as its manufacture. This part also formulates the extension of new obligation to give Intellectual Protection rights protection to integrated circuit design and undisclosed information.

Part III consisting of 5 Chapters and 20 Articles formulates in detailed the necessity of the members of WTO to impose the regulations of Intellectual Property Rights on Intellectual Property Rights violation. In addition, this part also formulates in detailed the procedures of the enforcement of Intellectual Property Rights through the mechanism of administration and civil recovery, injunction, crime procedure and detailed customs procedure on the allegation of Intellectual Property Rights violation of imported and exported products.

Part IV clearly explains the obligation to implement the procedure of obtaining and maintaining of Intellectual Property Rights that is inter-parties. Part V also explains clearly the necessity of the members to manage and implement the rules of Intellectual Property Rights transparently. This part also contains clear formulation about the necessity to settle a dispute regarding the implementation the protection of Intellectual Property Rights through WTO Disputes Settlement Body of Intellectual Property Rights for all members of WTO.

Part VI contains the regulation of necessity to implement the contents of the agreement by the WTO members. This regulation is clearly elaborated to time limit suited to the categories of the parties. On the last part if the formulation about the necessity, TRIPs Council does monitoring to the implementation of the agreement, formulation of conditions of agreement implementation, very rigid formulation of requirements and formulation about amendment as well as international cooperation.

The formulation of the existing articles in TRIPs agreement is very clear or not ambiguous either the one regarding its substantive regulation or the one regarding the procedures of the enactment. Thus, the possibility of interpretation is very limited (substantial but limited of interpretation). The clear formulation existing in TRIPs does not allow WTO members to escape from the necessity to follow the provisions of the agreement. This also shows that precision dimension in this agreement is very strong (hard). 


\subsection{Delegation Dimension in TRIPs Agreement}

Delegation is the third element of theory of legalization, which refers to the third party given authority to implement, interpret and apply the rules in the agreement, settle a dispute, and possibly make a new rule. Delegation is an important part of an international agreement because it will be difficult or effective to implement all forms of provisions in the agreement without the existence of delegation. Delegation functions as a party that has authority to implement, interpret and give punishment to the party that violates the agreement. This dimension frequently becomes the determination of whether an international agreement is effective of not.

Delegation dimension in TRIPs agreement seems explicit. Regarding the implementation of TRIPs agreement, the WTO members have the obligation to implement all TRIPs agreement into their own national law (implementing legislation) thoroughly. Although there is still possibility to do reservation (requirement), the possibility is very small because reservation needs the agreement from all WTO members (Article 72). Commitment of WTO members to implement all the contents of the agreement has been regulated explicitly and on scheduled. For developed countries, the implementation is maximum one year after the enactment of TRIPs agreement $\left(1^{\text {st }}\right.$ January 1995). For developing countries, the implementation is four years after the enactment of the agreement, and for under developing countries, the implementation is ten years after the enactment of TRIPs agreement (Article 65).

This delegation dimension brings about the implication of harmonization in the system of Intellectual Property Right protection in all WTO countries because the rules of Intellectual Protection Rights protection (covering availability, procurement, enactment and enforcement of Intellectual Property Rights) in all WTO members refer to the standards of protection contained in all provisions of TRIPs agreement. The obligation to implement the provisions of the agreement through national law by all WTO members must be transparent (Article 63). TRIPs agreement also gives authority to TRIPs Council to do the monitoring of the implementation and enactment of the provisions in TRIPs agreement in all WTO members.

Delegation dimension regarding the settlement of agreement dispute and enforcement of the implementation of the provisions in the agreement through domestic jurisdiction in all member countries is very binding. The members of WTO has an obligation to regulate rules that give authority to local courts to conduct enforcement to the violation of the agreement through administrative recovery, civil lawsuit and crime action besides the obligation to make rules for the enforcement of the contents of the agreement through cross border measure. If the members fail to do their obligation, they may be sued in WTO trial forum, DSB, or they must obey Article XXII and XXIII GATT 1994 about "understanding on Rules and Procedures Governing the settlement of Disputes" or so called "Integrated Disputes Settlement-IDS". Disputes settlement of Intellectual Property Rights enforcement through this procedure allows the parties to take unilateral action or even cross-retaliation if DSB decision is not implemented by the parties.

Delegation dimension in TRIPs agreement aforementioned shows high indication as international agreement either from Disputes resolution indication or rule making and implementation indication. From all of explanation regarding obligation dimension, precision and delegation in TRIPs agreement, all of them show high indication so that it can be concluded that TRIPs agreement is categorized hard international agreement. 
All the provisions stated in TRIPs Agreement and its amendment are discussed in international relation perspective especially based on neorealism or structural realism. They are the reflection of an anarchy international system which means that a state will always look for wealth and power in it. According to Kenneth Walzt's view, anarchy will be always present because there is no higher authority that can guarantee the presence of balance, so the state acts merely based on its own interest, meaning that the state chases as much as power as they wish. In anarchy system, a state cannot depend on other countries or institutions, but only to itself (self-help). ${ }^{28}$

In line with Waltz's view, Robert Gilpin views a state as self-regarding entity in an international anarchy realism. According to Gilpin, international relation will tend to become an arena of struggle for a state as an independent actor in an anarchy global system in order to gain wealth and power. ${ }^{29}$ Furthermore, still according to Gilpin, the struggle of power among the legitimate states or countries ultimately will generate a change of power. A country that is adaptive and has technology innovation element, supporting social internal factor, and strong military will have high domestic agential power that can be used to obtain important position or noteworthy place in international system. ${ }^{30}$

Since the beginning of the discussion of the making of TRIPs agreement to its amendment and the process of Intellectual Property Rights enforcement in WTO frame is similar to what is described by Gilpin and Waltz in the previous sub-chapters. Gilpin and Waltz describe that basically international system is a system of struggle for power of countries involves in it. In WTO, there is capability distribution that is not equal, especially among developing countries and countries with developed industry dominated by developed countries such as USA and other developed countries (West European countries and Japan). Countries with developed industry and strong domestic elements related to the interest of Intellectual Property Rights protection are multinational corporations (MNC), the holder of international Intellectual Property Rights in the field of pharmacy, software, automotive and telecommunication industry so that this condition allows developed countries to be more adaptive to master and dominate a structure of an international system.

This condition is examined according to scholars of critical study which believe that legal logics and structures arise power relationship in society (in this context, international society). The existence of law is to support interests or classes in society that form the law. In this thinking frame, they who are strong (countries with developed industry) use law instrument to oppress the society (developing countries) as a way to maintain their position. Regarding that there is economy and political domination of Northern countries over third world countries. Consequently, provisions of international law are basically enacted to guarantee the interests of economy domination of Northern countries. 31

Tendency to adopt provisions of international law into national law is inevitable in this globalization era in part because interdepended among the countries is getting stronger, even there is no country in this world that can free itself from this

28 Griffiths, M. (ed). (2007). International Theory for the Twenty-First Century, New York: Routledge, p. 19.

29 Wendt, A. (2003). Social Theory of International Politics. Cambridge: Cambridge University Press, p. 97.

30 Hobson, J.M. (2003). The State and International Relations. Cambridge: Cambridge University Press, p. 33-35.

31 Samekto, A. (2008), Justice Not for All, Kritik Terhadap Hukum Modern dalam Perspektif Studi Hukum Kritis. Yugyakarta: Genta Press, p. 55-56. 
interdepend relationship with other countries. Not only is the interdependence in economy, technology or politics, but also in national law and international law. Although the implementation of international law is inevitable, provisions that should become the authority of national law must still be respected because in order to implement provisions of an international law in national jurisdiction, it is necessary to consider the issues, social, political and economic condition substantially, structurally and culturally in each party countries participants of the agreement, which is different in one another.

Substantial provision of Intellectual Property Rights, procedure and enforcement of Intellectual Property Rights, and the implementation of full compliance in TRIPs agreement show that the order of international law is no longer coordinative which accommodates the interest of the party countries, but it has reached the stage of subordinate order of law because authority of national law is faced with the authority of supra national power. The power of supra national is shown in the form of Supervision Council and Council for Trade Related Intellectual Property Rights which monitor the implementation of TRIPs Agreement in the party countries participants of the agreement. In addition, the party countries are also faced with compulsory mechanism of disputes settlement through Dispute Settlement Body (DSB) and the possibility of getting cross-retaliation if the parties are disobedient and violate TRIPs Agreement.

\section{Conclusion}

Obligation dimension of TRIPs agreement establishes obligation of the parties' countries to do conformity or full compliance to some agreement in Intellectual Property Rights as minimum requirement. The parties are not given a chance to propose requirements apart from the agreed requirements that must be obeyed by the parties. This obligation shows a very strong binding power of TRIPs agreement (hard). While precision dimension in TRIPs agreement is contained clearly in the formulation of the rules of the agreement. The use of the word "shall" shows strong imperative. It does not make other interpretations besides that all members of WTO have to implement Intellectual Property Rights protection. Precision dimension indicates that the agreement is very strong (hard). Last but not least, delegation dimension in TRIPs agreement seems explicit. Regarding the implementation of TRIPs agreement, WTO members have the necessity to implement all TRIPs agreement into their own national law (implementing legislation) thoroughly. This delegation dimension indicates a high degree as international agreement either from Dispute resolution indication or from rule making and implementation indication. All of the dimensions-obligation, precision, and delegation-in TRIPs agreement show high indication, so it can be concluded that TRIPs agreement is an international agreement categorized as hard law.

The order of international law is no longer coordinative which accommodates the interest of the party countries, but it has reached the stage of the order of subordinative law because national law authority is faced with the power of supra national. The power of supra national is shown in the form of Supervision Council and Council for Trade Related Intellectual Property Rights which monitor the implementation of TRIPs agreement in the party countries participants of the agreement. The party countries are faced with the compulsory mechanism of dispute settlement through Dispute Settlement Body (DSB). 


\section{References}

Abbott, K.W., and Snidal, D. (2000). "Hard and Soft Law in International Governance." International Organization, 54(3), 421-456.

Benvenisti, E., and Hirsch, M. (Eds). (2004). The Impact of International Law on International Cooperation: Theoretical Perspectives. New York: Cambridge University Press.

Boyle, A.E. (1999). "Some Reflections on the Relationship of Treaties and Soft Law," International Law Quarterly, 48, (4): 901.

Dunoff, J.L., and Pollack, M.A. (eds.). (2012). International Law and International Relations: Synthesizing Insights from Interdisciplinary Scholarship. New York: Cambridge University Press.

Griffiths, M. (ed). (2007). International Theory for the Twenty-First Century, New York: Routledge.

Hobson, J.M. (2003). The State and International Relations. Cambridge: Cambridge University Press.

Kusumaatmadja, M. (1982). Pengantar Hukum Internasional, Buku I Bagian Umum. Bandung: Rosda Offset.

Samekto, A. (2008), Justice Not for All, Kritik Terhadap Hukum Modern dalam Perspektif Studi Hukum Kritis. Yugyakarta: Genta Press.

Shaffer, G., and Pollack, M.A. (2012). "Hard and Soft Law: What Have We Learned?" Minnesota Legal Studies Research Paper No. 12-17. Available at SSRN: https://ssrn.com/abstract $=2044800$

Shaw, M.N. (2003). International Law, Fifth Edition, Cambridge University Press.

Wendt, A. (2003). Social Theory of International Politics. Cambridge: Cambridge University Press.

Winarno, B. (2011). Isu-isu Gobal Kontemporer. Yogyakarta: CAPS. 